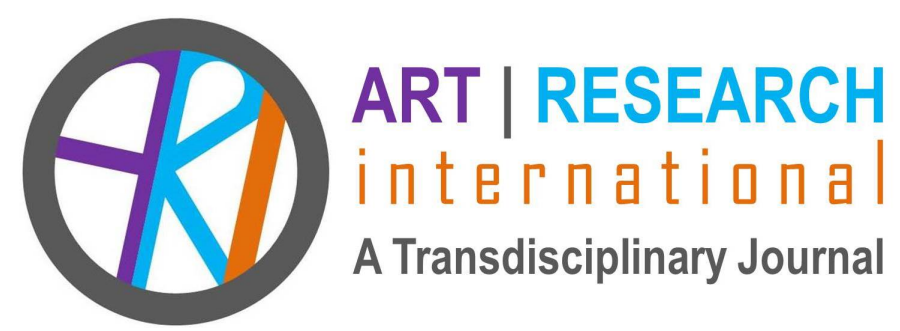

\title{
EDITORIAL FOR SPECIAL ISSUE: MAKING AS METHOD: REIMAGINING TRADITIONAL AND INDIGENOUS NOTIONS OF “CRAFT” IN RESEARCH PRACTICE
}

\author{
Esther Fitzpatrick \\ Guest Co-editor \\ University of Auckland, New Zealand \\ e.fitzpatrick@auckland.ac.nz \\ Rosemary C. Reilly \\ Guest Co-editor \\ Concordia University \\ rosemary.reilly@concordia.ca
}

Esther Fitzpatrick, PhD, is a Senior Lecturer in the Faculty of Education and Social Work at the University of Auckland, New Zealand. Throughout her doctorate, as an autoethnographic project, Esther became increasingly interested in craft and ekphrastic poetry as innovative methods, to make sense of complex issues for emerging identities in postcolonial societies. She has since published broadly and has a variety of teaching and research interests including culturally sustaining pedagogies, narrative inquiry, critical theory and pedagogy, arts-based methods, philosophy of education, postcolonial studies, white identity, decolonising practices, neoliberalism, and teacher identity. Esther is particularly interested in innovative research collaborations.

Rosemary C. Reilly, PhD, CCFE, is an associate professor in the Department of Applied Human Sciences at Concordia University in Montréal, Québec. She is also a Member Scholar Academic of the International Institute for Qualitative Methodology. Her 
research interests include the impact of trauma on neighbourhoods and communities, collective healing strategies and systemic resilience, creativity, and qualitative and artsbased research methodologies. She also learned embroidery as a child from her mother, knitting from her mother-in-law, and continues to explore crafting as a research methodology and for her own well-being. 
Felicia Semple (2019), a blogger who writes about the connection between handmaking and well-being, recounted a story about an off-handed remark made by her son when he came upon her knitting in her study. "Look at you, sitting there knitting like some old granny." She responded, "My love, how many granny's [sic] do you actually know who knit... nearly every woman you know knits, and none of them are grandmas, so why are you perpetuating a stereotype that is not true in your world. For that matter, where did you even get that stereotype... You are surrounded by people who knit who are in their 30s and 40s." Semple uses this incident as the launching point for interrogating the notions of craft as trivial, useless, ridiculous, indulgent, privileged, and worthy of scorn and derision.

\section{Craft is not trivial.}

For eons, human beings, most often women, have gathered together, or worked alone, to tell their stories through crafting, whether it be with thread, fabric scraps, beads, clay, yarn, wood, paper and leather, reeds, or other ordinary materials - the original bricoleurs constructing beauty, meaning, and culture from whatever was at hand, transforming everyday objects. Passed down from one generation to the next as an embodied practice, crafting became a social process for empowerment, action, and expression. But crafts have a deeper significance: the hierarchical classification of art versus craft mirrors longstanding power and status differences based on gender, class, social, and economic structures (Lippard, 2010).

\section{Craft is not useless.}

Crafting is not only a way of embodied knowing, it can represent covert action when done in a protest or resistance context. Craftivism is a term popularized by North Carolina activist Betsy Greer. It refers to the use of politically engaged crafting methods as a strategy to examine and challenge contemporary issues and policies (Black \& Burisch, 2010), and has a long historical tradition. Throughout ancient Greek writings (see The Odyssey), there are repeated instances of women weaving messages into fabric when they were silenced, using these objects to testify to their experiences of sexual or gender-based violence (W. N. P. Radio, 2019). Quilts made by enslaved African women in the antebellum southern United States were a way to secretly pass on outlawed African spirit traditions (Fry, 2002). Sojourner Truth engaged in knitting and needlework as a form of resistance (Sophia Smith Collection, n.d.). Songs crafted by Japanese women mill workers in the 1880 s were able to sustain them during strikes for better condition and wages (Kondo, 2009). The NAMES project AIDS quilt documented lives that history might have neglected, and concretely illustrated the devastating impact 
of the disease (Lewis \& Fraser, 1996). The arpillera movement in Chile allowed ordinary women to defy a military dictatorship by embroidering their sorrow onto scraps of material as a means of protest and resistance, memorializing the disappeared (Agosín, 1996).

\section{Craft is not ridiculous.}

When these craft-making practices are employed in the research process, they can provide a significant way to tap into hidden stories, stories that reside in our bodies and in our pasts, stories that shape our current understandings and positions. In response to increasing globalization, traditional and Indigenous craft-making practices are being reimagined as important ways of remembering and reclaiming - of disrupting dominant discourse and making sense of our worlds (Fitzpatrick \& Bell, 2016). Crafting requires us to listen once again to our bodies. It can allow us to tell our stories without the constraints of the written word, and to identify differently with our social context. When combined with research, craftivism can raise consciousness, create wider conversations about social issues, challenge injustice, fashion tools for proactive political protest, and find creative solutions to conflict (Baumstark et al., n.d.).

The idea for this special issue was woven from several disparate and distinct threads.

\section{For Esther}

It began (again) one summer, when the new school year was just beginning - a time of year when everything is still possible. I had agreed to meet with a student who was contemplating a Masters and wanted to discuss the possibility of supervision. I remember we sat outside the Faculty of Education's tent cafe at a picnic table, so her two young children could run around on the tennis courts, and we talked seriously about culturally responsive practice and her various education experiences. I was imagining this shaping up to be an interesting and traditional qualitatively designed study. Every methods textbook has formulae for this. I had also imagined that this meeting was about to end, the kids were getting scratchy and we had covered everything, just needed to discuss where to next. That was when she drew my attention to a large woven bag she had sitting down at her feet. She looked across at me and asked, "I've brought something with me - could I show you?" "Sure," I replied. Then she reached down and took out of the bag a bundle of fabric patches, placing them gently on the large 
wooden picnic table. "Do you think I could make a quilt as part of my methodology?"

I had started noticing researchers doing wonderful things as method part way through my doctorate. First, at the International Visual Methods conference in Wellington in 2013, I learned about the making of arpillera in Chile. Phiona Stanley at the 2017 Critical Autoethnography Conference in Melbourne sat and knitted in response to participants shared voices and created an art piece. I later sat with Hinekura Smith who taught me the method of flax weaving.

For Rosemary, it started early.

My mother, Emma, was a first generation Italian born in the US. Historically, Italy has had a long tradition of bright and colourful needlework. Though embroidery is generally considered a symbol of luxury and wealth (Quaresmini, 2015), this tradition is firmly rooted in Italian peasant culture. Embroidery was used to celebrate their relationships with God, nature, food, and iconic images from the pre-Christian past. During special festivals women would wear beautiful dresses and bodices, handcrafted with detailed embroidery (Grabianowski, 2011). Dresses, stitches, and patterns were passed down from mothers to daughters for generations. And when I was little, perhaps around the age of 4 or 5 , she passed onto me the skill of embroidery, though her knowledge was limited by her own mother's death when she was only 13. Unfortunately, in my teens, I forsook the practice. It seemed to me at the time, foolishly so, that it was unseemly for a feminist to engage in needlework.

When I married into my husband's family in the 70s, I was gifted with a knitted family afghan. Everyone in the Nerenberg family had one, each with their own distinctive color palette. My mother-in-law, Arona, learned to knit and sew from her mother, Lilly, who took in sewing to supplement the family income. Arona's first career was as a seamstress in the same clothing factory as her father. She made clothes and altered them. She was a dollmaker. But, later in life, her forté was knitting, and she made her distinctive afghans for all members of the family. She taught me how to knit, though I have an odd way of knitting. She was left-handed. I am right-handed. So I knit like a left-hander with my right hand. In this way, she is with forever with me. 
A third thread was introduced when Esther and Rosemary met at the Critical Autoethnography conference in Melbourne in 2016. Rosemary was presenting on the use of doll-making for interrogating and communicating data about difficult but courageous lived experiences (Reilly, 2016), citing Esther's work with Avril Bell on using arpillera to speak with the ghosts of their white European colonial ancestors (Fitzpatrick \& Bell, 2016). From opposites side of the world, across a distance of $16,726 \mathrm{~km}$, craft created a connection.

\section{Craft is not indulgent.}

In this special issue of "making as method" we aim to help shift the cultural narrative about craft by celebrating a diverse range of creative researchers who disrupt Western ways of knowing, celebrate a reclaiming of Indigenous knowledge and methods, provide space for decolonising practices, and in this digital age, reimagine traditional and Indigenous notions of craft in research. These authors all theorise their craft and provide, in one issue, a rich and varied theoretical justification for "making as method." As articulated by Neil Cunningham (2017), "We are at a fascinating inflection point, where crafts, old and modern, are intermingling, and opening many new avenues ..." (para. 7). Craft is in the process of being reimagined in a technological age. Treadaway (2007) describes a hybrid practice, where digital techniques are combined with textile craft skills to support and enhance creative practice. However, recognition of the significance of "making" is consistent.

Our hands help us think and physical making provides opportunities for serendipitous and accidental creative insights that the logic and control of the machine can often inhibit. By combining traditional textile handcraft, such as hand embroidery, screen printing and hand painting, digitally printed surfaces can be embellished... (Nimkulrat, Kane, \& Walton, 2016, p. 30)

\section{Craft is not privileged.}

In this issue Indigenous researchers from Canada, Australia, Hawaii, Greece, and Aotearoa New Zealand provide thoughtful narratives, which explore and present traditional craft making as method. Further, collaborations between Indigenous and nonIndigenous researchers and participants through "making as method" provide ways we might begin to work differently - together. Other research collaborations, in this special issue, demonstrate how "making as method" can be employed to generate stories differently, and often from overlooked voices or vulnerable participants - those who require us as researchers to be ethically creative in our endeavours. Several other 
researchers also draw on "making as method" to explore their own identity journeys and disrupt normative assumptions.

\section{Craft is not worthy of scorn and derision.}

This issue aims to conclusively demonstrate that.

\section{Art/Research Theoretical Musings}

Indigenous Māori scholar Hinekura Smith, from Aotearoa New Zealand (Tribes: Te Rarawa, Ngāpuhi, Te Ati Awa) (The University of Auckland), in "Whatuora: Theorizing 'new' Indigenous methodology from 'old' Indigenous weaving practice” theorises a Māori weaving practice as a decolonising research methodology for her research (Smith, 2017). She explores the lived experiences of eight Māori mothers and grandmothers as they wove storied Māori cloaks. Tiffany Dionne Prete, from the Blood Tribe of the Blackfoot Confederacy, (University of Alberta), in "Beadworking as an Indigenous Research Paradigm" provides three principles that form the conceptual basis of beadworking as an Indigenous research paradigm, arguing the method as an act of resistance. She illustrates how beading a pair of moccasins as a gift to a knowledge holder allowed her to engage with the Blackfoot natural laws of the universe. She argues that Indigenous research in the academy is relatively new, and should be used as a means to decolonize her people (Smith, 1999). Katerina Konstantinou (Panteion University of Social and Political Sciences, Greece), and Aris Anagnostopoulos (University of Kent), in "Interweaving contemporary art and 'traditional' crafts in ethnographic research" designed a collaborative project using "traditional" crafts in an open art-studio in a rural community at a mountain village in Crete, Greece. The open art studio is a response to Onciul's (2015) theorized engagement zones. Importantly, they highlight the tensions that arise in collaborative projects and also note that the process is not, or not only, the evocation of a historical experience, a past "already there," but also a meeting ground between the embodied, sensuous knowledge of the past and our formal, social-scientific and historical methods of approaching it. Eveliina Sumelius-Lindblom (University of the Arts, Helsinki), in "The pianist's perception as a working and research method: Encountering intertextual and phenomenological approaches in piano playing" explores her role as a pianist. She defines craft as a multilayered entity, which is not solely confined to "making music" but includes - as an inherent part of the craft - conducting research as well. She argues that making decisions in piano playing is comparable to Merleau-Ponty and Landes' (1945/2014) concept of the "intentionality of the body." Founded on an epistemic perspective that 
knowledge is gained through a dynamic process of experientialism (Savin-Baden \& Major, 2013).

\section{Art/Research In Action}

Indigenous scholar Una Kimokeo-Goes (Linfield College), in "The quilt speaks: Crafting gender and cultural norms in Hawaii" demonstrates how her Hawaiian ancestors, while adopting the colonial practice of sewing and quilt making, simultaneously also subverted aspects of the missionary belief system. She describes how quilting allows for her "entanglement of matter and meaning, past and future" (Barad, 2007, p. 383) and argues that, while her craftwork is far from traditional, the missionary skills of sewing and quilting and her Indigenous undertones remain. Christine Rogers (RMIT University, Melbourne), in "The needle as medium: Using embroidery to speak to ghosts" as an adoptee, uses the practice of embroidery to "speak to/with her Indigenous Māori ghosts." Recently discovering her Ngāi Tahu ancestors, through the vernacular of craft she "represents the unrepresentable" (Holloway \& Kneale, 2008, p. 297). Rogers describes how "[a]s the words and Māori and European motifs become three-dimensional under my fingers, no longer computer-generated and perfect, but wonky, flawed and human, I can feel a connection being made between me and the work, and a connection to my past."

From Australia, Indigenous scholars Tracey Bunda, a Ngugi/Wakka Wakka woman, (University of Southern Queensland), Robyn Heckenberg, a Wiradjuri woman, (University of Southern Queensland), and collaboraters Kim Snepvangers (The University of New South Wales), Louise Gwenneth Phillips (The University of Queensland), Alexandra Lasczik (Southern Cross University), and Alison L Black, (University of the Sunshine Coast) in "Storymaking belonging" describe their experimental making research methodology. Stitching, threading, imaging, dancing, and painting, they argue that, "sometimes data invites more of us. To be physically held and touched, through hands creating and crafting with matter, cultivating a closer connection to the fibres, threads, textures and sinews of data." Ruth Beer (Emily Carr University of Art and Design) and Caitlin Chaisson (Emily Carr University of Art and Design) in "A Canadian selvage: Weaving artistic research into resource politics" use a contemporary weaving method to shed light on the present entanglement between Indigenous and non-Indigenous cultural heritage, ecological perspectives, and resource extraction. Through their collaboration they explore the ways fibers, land, and networks penetrate both woven fields and resource fields, and how arts-based research can support critical reflexivity when addressing some of these connections. Drawing on Auther (2010), they 
question the motives and politics behind limited views of the relationship between art and craft, and see craft as offering a vital and rigorous perspective on the world.

In her autoethnographic project Julie Brien (The University of Auckland), in "Stitchery me, stitchery do" describes herself as having "always been a crafter, and a sometimes quilt maker." Working in collaboration with her participants to explore the practice of culturally responsive pedagogies she defines crafted as something that is created with care, time, diligence, skill, and technique, whereas the word mastery is associated with skill and technique (Shiner, 2012). Learning to listen to the land and sharing stories and poems from that listening, Margaret McKeon (University of British Columbia), in "Patterns repeat: Transformation through creativity in research about land and colonialism" describes her poetic "writing as her humble offering of reciprocity". Applying the term crafting to the creation of her own life and art making, she explores her becoming as a descendent of white settlers on unceded Musqueam territory. She learns to stand and dance stories, with the Indigenous people and with her ancestors. She references Cardinal and Armstrong (1991) who speaks of "creativity as a human responsibility or purpose of seeking through the unknown to bring forward the new."

Creating spaces for overlooked voices or/and the vulnerable to be heard, Corinna Peterken (Brigham Young University), through "Crafting living inquiry with a quilt of children's images" with young children, designed a collaborative co-creation of a quilt as a living inquiry to provide spaces for learning and knowledge making. Corinna worked as artist, researcher, and teacher (Springgay, Irwin, Leggo, \& Gouzouasis, 2008), and describes how she used "playful experiences with our crafting to create places where we could use quilting and the quilt to 'dip into the spaces between knowledges already made' (Ellsworth, 2005, p. 142)." For six months, tapestry artist/ researcher Ilona Pappne Demecs (Queensland University of Technology), with researcher Evonne Miller (Queensland University of Technology), in "Woven narratives: A craft encounter with tapestry weaving in a residential aged care facility" moved her studio into an aged care home in Australia to conduct a participatory art project. In collaboration with the residents they used a rare craft (tapestry weaving) that develops at a slow pace, enabling conversations, connections, and suiting the slower pace of older age. Kathryn Grushka (University of Newcastle), Michelle van Gestel (University of Newcastle), and Clare Skates, fibre artist/tapestry weaver and researcher, collaborate together through the act of exploring their shifting identities through a continuous folding of the artists' own encounters with the world of contingencies in the telling and re-telling of personal narratives through art making. Through their "making as method" they embrace the idea that "truth is producing 
existence" (Deleuze, 1990, p. 134), positioning their research in the post-qualitative turn, wherein knowing is not privileged over being (Lather \& St. Pierre, 2013).

Jessica Smartt Gullion (Texas Woman's University), in "Pathology: A Diffractive Encounter of Machine/Body" uses art journaling, a material discursive interface, and created images and text while thinking about her experience of undergoing surgery and diffracting through Haraway's (2016) ideas about cybernetics and machine bodies.

Break apart.

"Cutting together-apart

(one move)

In the (re)configuring of spacetimemattering (Barad, 2014, p.168).

Allison Ray Reagan (Texas Woman's University), in "Quilt/cARTography: Using craftivism to explore food insecurity on a college campus" employs a constructivist approach to creating learning environments by incorporating craftivism-based instructional design techniques to engender learning through Quilt/cARTography. She further contends that arts-based quilts provide an effective method for the dissemination of data. Phiona Stanley (Napier University, Scotland), in "Crafting a DIY campervan and crafting embodied, gendered identity performances in a hyper-masculine environment" provides a visual and textual narrative describing her journey of "hanging out with a bunch of tradies in a diesel mechanic's workshop." Beautifully capturing the "gendered identity performances" while involved in a campervan conversion project which she describes as "technical" and "physical" and may be regarded as a rather more masculine pursuit (e.g. Bratich \& Brush, 2011). Zabe MacEachren (Queen's University, Canada), in "Unplugged craftivism: A story of humans and environmental education" takes us back to what she describes as the first rule of craft making knowing where to find the material you need to live-the stuff of life, as Indigenous author Lee Maracle (1996) refers to it. Zabe posits that craft belongs to the story of humans and their interaction with the environment - and is probably the most endangered outdoor experience in the modern world. Belinda MacGill (University of South Australia), in "Craft, relational aesthetics and ethics of care" couples a feminist reading of craft with Ahmed's (2003) notion of accumulation. She argues crafting is a powerful political weapon that resists neoliberal manifestations of being in this world. Her practice in craft involves modifying sea balls found on the beaches in the intertidal zones in South Australia. 
I walk in the stories of colonization in melancholic silence and traverse the deep ruptures that only the earth can heal and in so doing the Sea craft Balls act as a way to sew myself back into a place of relationality where the assemblages work metaphorically; signifying the possibilities of postcolonialism.

\section{Art/Research Reviews}

For the review section we invited five arts-based researchers to each write an ekphrastic review for one of the "making as method" articles presented in this special issue. We believed crafting poetic reviews captured the essence of the issue, and the submissions. As Faulkner (2017) reminds us when writing research poetry

many arts-based researchers are also poets making us poet-researchers, research-poets, or simply poets who do and use research in our poetic work. The similarities reside in the use of process-oriented craft to explore reality, create something new, disrupt usual ways of thinking and create embodied experience. (pp. 213-214)

These ekphrastic works involve a poetic response to an aesthetic form through interpretive practices (Kulnieks \& Young, 2014; Maddison-MacFayden, 2013). This form of ekphrasis (where one art form is used to respond to another art form to reveal, communicate and illuminate the message) is a form of poetic inquiry that is consistent with Prendergast's (2004) definition - a method to "draw out or make clear" (p. 3) the practice of creating art in response to art. Ekphrasis can be used as an interplay between visual, textual, and performative works (see Fitzpatrick, 2015).

Prendergast (2004) highlights five important categories from Bruhn (2000) on the use of ekphrasis in inquiry. First, the potential for ekphrasis to recreate through other art forms a response to an original art work (transposition). Second, the potential for ekphrasis to add non-spatial, for example, sensory, dimensions (supplementation). Third, it provides a stimulus to trigger memories (association). Fourth, it provides the researcher with a critical eye (interpretation). Finally, ekphrasis has the potential for playfulness in the crafting of the new art work.

The ekphrastic reviews, a series of poems, are in the same order as their associated "making as method" articles in the journal. Fetaui losefo (The University of Auckland), in "Settling the soul through va" responds to Hinekura Smith's weaving of Māori cloaks. Sandra Faulkner (Bowling Green State University), in "Pākehā sampler" 
responds to Christine Roger's embroidery to speak to ghosts. Adrian Schoone (Auckland University of Technology), provides "An ekprhastic review of llona Pappene Demes and Evonne Miller's tapestry weaving" in a care home. James Burford (La Trobe Univerisity), writes "An ekphrastic poem for Phiona Stanley" and her gendered identity performance of her campervan conversion project. Rosemary Reilly (Concordia University, Canada), entangles her own story through an ekphrastic review of Belinda MacGill's Sea Craft Ball's in "Entanglements across time-space." 


\section{REFERENCES}

Ahmed, S. (2003). Affective economies. Social Text, 22(2), 117-139.

Agosín, M. (1996). Tapestries of hope, threads of love: The arpillera movement in Chile 1974-1994. Albuquerque, NM: University of New Mexico Press.

Auther, E. (2010). String, felt, thread: The hierarchy of art and craft in American art. Minneapolis, MN: University of Minnesota Press.

Barad, K. (2007). Meeting the universe halfway: Quantum physics and the entanglement of matter and meaning. Durham, NC: Duke University Press.

Barad, K. (2014). Diffracting diffraction: Cutting together-apart. Parallax, 20(3), 168-187. DOI:10.1080/13534645.2014.927623

Baumstark, M. C., Carpenter, E., Davies, J., Gooderham, T., Greer, B., Harvey, B., Marsh, R., Marvel, M., Miller, A., Nectar, I., Nielsen, A., Poppelin, E., \& Varvis, C. (n.d.). Craftivism manifesto 2.0. Retrieved from http://craftivism.com/wpcontent/uploads/2017/04/craftivism-manifesto-2.0.pdf

Black, A., \& Burisch, N. (2010). Craft hard, die free: Radical curatorial strategies for craftivism in unruly contexts. In G. Adamson (Ed.), The craft reader (pp. 609-619). New York, NY: Berg.

Bratich, J. Z., \& Brush, H. M. (2011). Fabricating activism: Craft-work, popular culture, gender. Utopian Studies, 22(2), 233-260.

Bruhn, S. (2000). Musical ekphrasis: Composers responding to poetry and painting. Hillsdale, NY: Pendragon Press.

Cardinal, D., \& Armstrong, J. C. (1991). The Native creative process: A collaborative discourse between Douglas Cardinal and Jeannette Armstrong. Penticton, B.C: Theytus.

Cunningham, N. (2016, January, 23). The reimagining of craft in a technological age. Retrieved from https://www.luxurysociety.com/en/articles/2017/01/reimaginingcraft-technological-age/ 
Deleuze, G. (1990). Negotiations, 1972-1990. (M. Joughin, Trans.). New York, NY: Columbia University Press.

Ellsworth, E. (2005). Places of learning: Media, architecture, pedagogy. New York, NY: Routledge.

Faulkner, S.L. (2017). Poetic inquiry: Poetry as/in/for social research. In P. Leavy (Ed.), Handbook of arts-based research (pp. 208-230). New York, NY: The Guildford Press.

Fitzpatrick, E. (2015). It's a tricky business: Performing poetry with the ghost. In P. O'Connor \& M. Anderson (Eds.), Applied theatre research: Radical departures (pp. 207-225). London, UK: Bloomsbury Methuen Drama.

Fitzpatrick, E., \& Bell, A. (2016). Summoning up the ghost with needle and thread. Departures in Critical Qualitative Research, 5(2), 1-24. DOI:10.1525/dcqr. 2016.5.2.1.

Fry, G.-M. (2002). Stitched from the soul: Slave quilts from the antebellum South. Chapel Hill, NC: University of North Carolina Press.

Grabianowski, E. (2011, July 25). How Italian traditions work: Traditional Italian clothing. Retrieved from http://people.howstuffworks.com/culture-traditions/ national-traditions/italian-tradition5.htm

Haraway, D. J. (2016). Manifestly Haraway. Minneapolis, MN: University of Minnesota Press.

Holloway, J., \& Kneale, J. (2008). Locating haunting: Ghost-hunter's guide. Cultural Geographies, 15(3), 297-312. DOI:10.1177/1474474008091329

Kondo, D. (2009). Crafting selves: Power, gender, and discourses of identity in a Japanese workplace. Chicago, IL: University of Chicago Press.

Kulnieks, A., \& Young, K. (2014). Ekphrastic poetics: Fostering a curriculum of ecological awareness through poetic inquiry. in education, 20(2), 78-89.

Lather, P., \& St. Pierre, E. (2013). Post-qualitative research. International Journal of Qualitative Studies in Education, 26(6), 629-633. DOI: 10.1080/09518398.2013.788752 
Lewis, J., \& Fraser, M. R. (1996). Patches of grief and rage: Visitor responses to the names project AIDS memorial quilt. Qualitative Sociology, 19(4), 433-451.

Lippard, L. (2010). Making something from nothing: Toward a definition of women's "hobby art." In G. Adamson (Ed.), The craft reader (pp. 483-490). New York, NY: Berg.

Maddison-MacFayden, M. (2013). This white woman has journeyed far: Serendipity, counter-stories, hauntings, and ekphrasis as a type of poetic inquiry. Morning Watch Journal of Educational and Social Analysis [Special Edition]. Narratives of becoming a researcher, 40, 1-15.

Maracle, L. (1996). I am woman: Native perspective on ecology and feminism. Vancouver, BC: Press Gang Publishers.

Merleau-Ponty, M., \& Landes, D. A. (2014). Phenomenology of perception. Abingdon Oxon, UK: Routledge. (Original work published in 1945)

Nimkulrat, N., Kane, F., \& Walton, K. (2016). Crafting textiles in the digital age. London, UK: Bloomsbury.

Onciul, B. (2015). Museums, heritage and Indigenous voice: Decolonizing engagement. New York, NY: Routledge.

Prendergast, M. (2004, July). Ekphrasis and inquiry: Artful writing on arts-based topics in educational research. Paper presented at the meeting of the Second International Imagination in Education Research Group Conference, Simon Fraser University, Vancouver, British Columbia, Canada. Retrieved from http:// www.ierg.net/pub conf2004.php

Quaresmini, L. (2015, December 1). A fashion history: An introduction to the history of embroidery [Web log post]. Retrieved from http://www.afashionhistory.com/ fashion-history/an-introduction-to-the-history-of-embroidery/

Reilly, R. C. (2016, July). Reclaiming my sister Medusa: A critical autoethnography about calling out and reporting sexual violence. Paper presentation at the Critical Autoethnography Conference 2016, Melbourne, Australia.

Savin-Baden, M., \& Major, C. H. (2013). Qualitative research: The essential guide to theory and practice. New York: Routledge. 
Semple, F. (2019, January 4). Craft is not trivial [Web log post] Retrieved from http:// thecraftsessions.com/blog/2019/01/04/craft-is-not-trivial

Shiner, L. (2012). "Blurred boundaries"? Rethinking the concept of craft and its relation to art and design. Philosophy Compass, 7(4), 230-244. DOI:10.1111/j. 1747-9991.2012.00479.x

Smith, H. L. (2017). Whatuora: Whatu kākahu and living as Māori women. (Unpublished doctoral dissertation). University of Auckland, Auckland, NZ. Retrieved from http://hdl.handle.net/2292/36334

Smith, L. T. (1999). Decolonizing methodologies: Research and Indigenous peoples. Dundein, NZ: University of Otago Press.

Springgay, S., Irwin, R. L., Leggo, C., \& Gouzouasis, P. (Eds.). (2008). Being with a/r/tography. Rotterdam, NL: Sense Publishers.

Sophia Smith Collection. (n.d.). Sojourner Truth seated with knitting. Retrieved from https://www.smith.edu/libraries/libs/ssc/popups/poptruth.html

Treadaway, C. (2007). Digital crafting and crafting the digital. The Design Journal, 10(2), 35-48. DOI:10:2, 35-48. 10.2752/146069207789272668

W. N. P. Radio (Producer). (2019, January 4). Knitting as protest [Audio podcast]. Retrieved from https://academicminute.org/2019/01/best-of-week-best-politicalscience-segment-jennifer-lemesurier-colgate-university-knitting-as-protest/ 